\title{
フレームモデルによる 2 層木質制振架構の地震応答解析 SEISMIC RESPONSE ANALYSIS OF 2-STORY WOODEN STRUCTURE WITH PASSIVE CONTROL SYSTEM USING FRAME MODEL
}

\author{
松田和浩*, 笠井和彦**, 坂田弘安*** \\ Kazuhiro MATSUDA, Kazuhiko KASAI and Hiroyasu SAKATA
}

\begin{abstract}
This paper proposes an accurate, member-by-member analytical model for two-story timber structures having energy dissipation walls and/or plywood shear walls. Various member joints are modeled by using nonlinear spring elements whose properties derived from numerous test results. The analyses were found to reproduce both local and global responses obtained from shaking table tests of a variety of two-story timber frames. Moreover, unsteady behavior of slip-hysteretic structure, energy absorption performance and deformation state of energy dissipation wall arranged in 2 nd floor are discussed.
\end{abstract}

Keywords: Frame Analysis, 2-Story Wooden Frame, Passive Control Scheme, Slip Response, Rocking Deformation フレーム解析，2 層木質架構，パッシブ制振，スリップ型履歴特性，ロッキング変形

1. はじめに

\section{1 背景}

木質住宅を比較的簡易に高耐震化する手段の一つとして、木質住 宅に制振技術を適用するための研究が数多くなされるようになった。 スリップ型の復元力特性を持つ木質構造では、変形すると剛性が低 下し損傷が顕著に現れるが、制振構造の場合はダンパーがエネルギ 一を吸収することで変形後も安定的な挙動を示すため、東日本大震 災のように複数回にわたる大規模余震に対しても有効と考えられる。 筆者らは数多くの実験を行うことで、木質制振壁の有効性を確認し

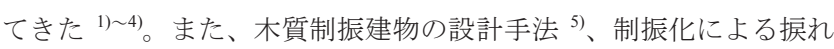
挙動の抑制 (6) など、様々な検討を行っている。その一環として、文 献 7 では多数の実験結果に基づき、詳細な 1 層木質制振架構のフレ 一ムモデルを作成した。本論文はその続報として位置づけている。 制振壁では、設置したダンパーと周辺部材の剛性バランスが悪い 場合、周辺部材が変形することでダンパー変形が減少し、エネルギ 一吸収効率が低下寸る。すなわちダンパーと周辺部材の剛性バラン スを適確に設定することが重要となるが ${ }^{8)}$ 、そのような細部の検討 を行う際に実験研究ではコスト面・労力面で検討に限界が生じる。 特に 2 層の検討をする場合、実験の規模も大きく、計測の点数や設 置法の制約から細部の挙動まで追うことは困難となる。一方、解析 ではそれらの制約が最小化され、人工的・材料的ばらつきの影響も 無しに論を進めることが可能である。質量や剛性のバランス、壁の 配置や設置法など、2 層架構に特有の問題は多く、その検討に向け て 2 層のフレームモデル解析で実際の挙動を再現できる必要がある。
文献 7 で言及したように、木質構造におけるフレーム解析の研究 例は比較的あり、また実務設計でもフレーム解析で検討を行う例も しばしば見られる。一方、モデルの作成法やその設定根拠に始まり、 実験結果との比較を通して全体・局所応答に至るまでの詳細な検証 を包括的に示した例は存在しない。そのような観点で、文献 7 の 1 層モデルに引き続き 2 層モデルの解析例を示すことは重要である。

\section{2 本論文の目的と構成}

以上より本論文の目的は、第一に文献 7 で示した制振壁・合板壁 による精密な 1 層木質制振架構のフレームモデルが 2 層木質制振架 構にも拡張できることを確認すること。第二に実験では把握困難な 2 層木質架構特有の問題について、筆者らが提案した制振壁を例に、 フレームモデルを用いて解析的に検討を行うことである。特に 2 階 に設置した制振壁は 1 階の制振壁よりダンパーのエネルギー吸収効 率が低下寸ることを実験により確認しているが3)、その理由につい ては不明瞭な点が多く、それについても明らかにする。

2 章では文献 7 で示した 1 層のフレームモデルを 2 層のフレーム モデルに拡張する手法を示す。 3 章では過去に行った 2 層木質架構 の振動台実験 ${ }^{3)}$, 4) の試験体モデルを作成し、振動台実験との比較を 通して解析モデルの精度検証を全体応答・局所応答の両面で行う。 解析モデルを用いた検討として、4 章ではスリップ型の復元力特性 が全体応答へ及ぼす影響について検討を行い、1, 2 層の質量比・剛 性比が変形モードに及ぼす影響についても言及する。5 章では制振 壁の配置や設置方法を変化させた場合の挙動の変化について言及し、 本制振壁においてロッキング変形の抑制が重要であることを示す。

\footnotetext{
* 東京工業大学建築物理研究センター 助教・博士 (工学) Assist. Prof., Structural Engineering Research Center, Tokyo Institute of Technology, Dr. Eng.

** 東京工業大学建築物理研究センター 教授・Ph. D.

*** 東京工業大学建築物理研究センター 教授. 工博 


\section{2 層木質架構フレームモデル}

\section{1 フレームモデル作成法の概要}

筆者らは文献 7 で図 1 に示すような $\mathrm{K}$ 型ブレースによる制振壁・ 構造用合板耐力壁のフレームモデルを作成し、モデルの妥当性を示 した。フレームモデルは柱や横架材等の部材の一般部を弾性梁要素 とし、スリップ型復元力特性を有する非線形バネでそれぞれを接合 することにより構成した。各壁の柱・横架材接合部は表 1 のような 仕様としており、それらをモデル化した各非線形バネは要素実験の 結果を元に、正負の繰り返し挙動を含めて挙動を忠実に再現できる ように作成した。ダンパー部には分数微分による粘弾性要素付绿 1 、 もしくは摩擦ダンパー用に完全弾塑性要素を用いた。なお、本解析 では地震応答解析ソフト『PC-ANSR』を用いた。

2 層木質架構にも基本的に 1 層と同様のモデルを適用した。ただ し 1 層架構と異なる部分として、2 階の柱脚に設置した引き寄せ金 物のボルト長さが長くなり、かつ直下の 1 階柱から反力をとること が挙げられる。本モデルでは柱脚金物と引き寄せボルトをそれぞれ 別のバネとしてモデル化しているため、柱の軸力変動によるボルト 軸力変動だけでなく、接合部の回転に伴うボル卜軸力変動や、それ による接合部の負担するモーメント抵抗も再現を可能としている。

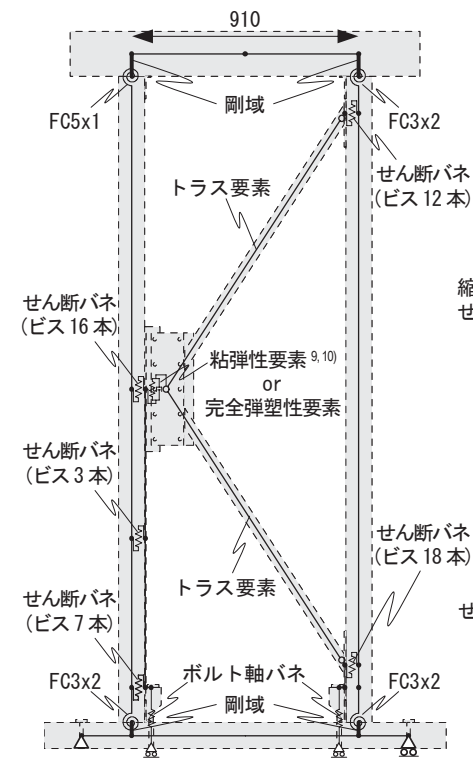

（a）制振壁

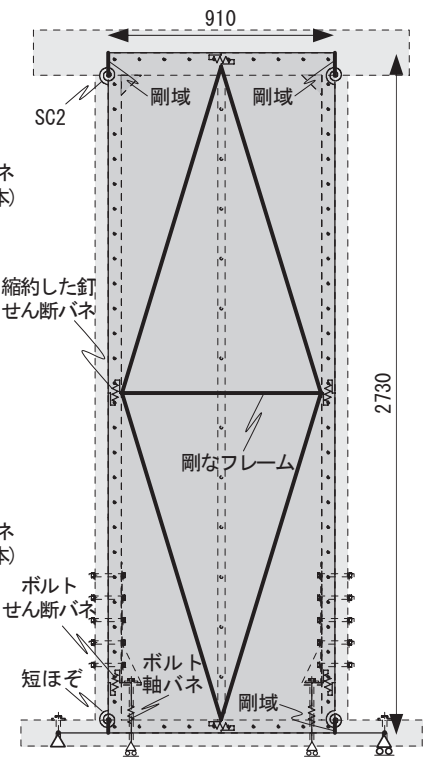

(b) 合板壁
図 1 制振壁・合板壁のフレームモデル概要 ${ }^{7}$

表 1 柱・横架材接合部一覧

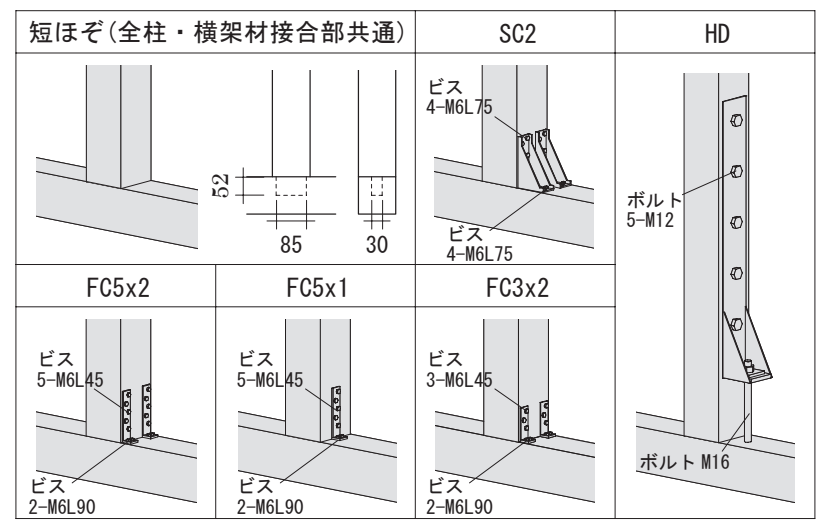

そのため、2 層架構へも容易に対応することができ、図 2 のように ボルトの軸バネの変更を行うのみで、モデル化を行うことが可能で ある。

\section{2 引き寄せボルトの復元力特性の設定方法}

引き寄せボルトの軸バネには、ボルトの軸伸びによる変形と金物 の変形の影響を含めて 1 つの非線形バネにモデル化している。制振 壁に用いた引き寄せ金物(例えば付録 2 , 図 A-1(c)) は、金物自身の変 形が極めて小さいことを実験により確認しているため、2 階柱脚用 のボルト軸バネでも、ボルトの軸剛性のみが変化すると考えた。ボ ルトの弾性時の軸伸びはボルトの締め付け長さ $L_{B}$ ・断面積 $A_{B}$ ・ヤン グ係数 $E_{B}$ で求まる軸剛性 $\left(E_{B} A_{B} / L_{B}\right)$ で概ね評価できることがボル 卜単体の要素試験からわかっている ${ }^{11)}$ 。塑性化後も同様の割合で変 化すると仮定し、図 3(a)に示すようにボルト軸バネの特性を設定し た。なお、本論文で扱った解析では、ボルトの軸力は常に $55 \mathrm{kN}$ 以 下であったことを確認している。

合板壁に用いた引き寄せ金物(表 $1, H D)$ は、図 4 に示寸変形状態の ようにボルトの軸伸びに対して金 物自身の変形がかなり大きい。ボ ルト反力用にも同じ金物を用いて おり、かつ 2 階引き寄せボルトの 締め付け長さが 1 階の場合の約 2 倍であったことから、図 3(b)に示 す 1 階用ボルト軸バネの $N_{B}-\delta_{B}$ 関 係に対し、柔性を 2 倍にすること で 2 階のボルト軸バネの復元力特 性を設定した。

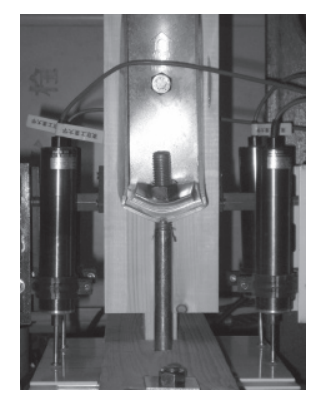

図 $4 \mathrm{HD}$ 金物の変形状態

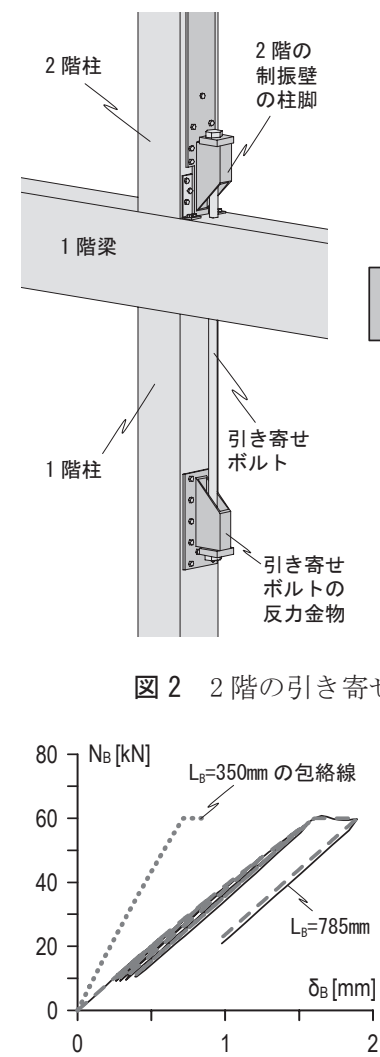

（a）制振壁用ボルト軸バネ

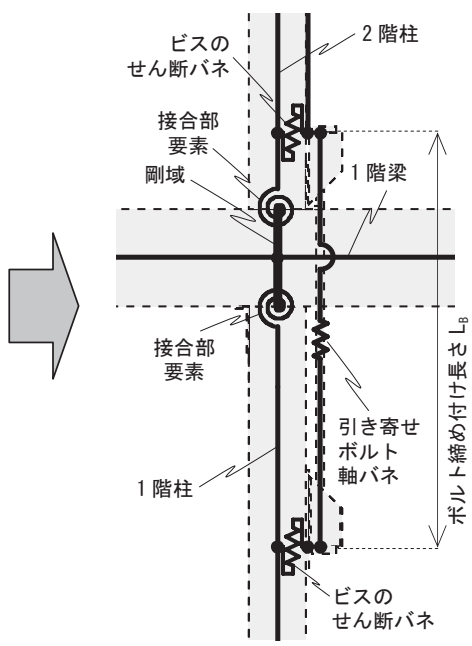

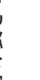

(n)

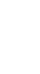




\section{2 層振動台実験との比較}

\section{1 モデルの概要}

2 層木質制振架構の地震応答解析精度を確認するため、図 5 に示 寸振動台実験 ${ }^{3), 4)}$ の試験体をフレームモデルに置換して解析を行い、 実験結果との比較を行う。試験体各階の四隅の独立柱は鉛直荷重を 負担させるために設置したもので、柱頭柱脚を短ほぞ+かすがいの 仕様としている。すなわち、接合部で曲げモーメントをほとんど負 担せず、四隅独立柱の層せん断力への寄与は極めて小さい。そこで 壁要素を配置した中央構面のみをモデル化する。モデル名は各文字 が壁の種類を表しており、Wが構造用合板耐力壁(Wood Panel)、V が 粘弾性ダンパーを有する制振壁(Viscoelastic )、F が摩擦ダンパーを 有する制振壁(Friction )、一 は耐力要素が無いこと、/より前が 2 階 の架構で後が 1 階の架構を意味する。また、W の前に数值がある場 合は $\mathrm{W}$ に対する剛性・耐力の比を示しており、その剛性・耐力にな ることを目標に試験体の釷配置を調整している。調整には文献 13 , 14 による理論を用いており、釘配列 2 次モーメント $I_{x}, I_{y}$ がそれぞれ 係数倍の数值となるように釷配置を定めた。

2 層モデルの例を図 6 に示す。中央構面は壁が市松状配置となっ ており、実験時に計測した各部材の重量を階高中央で各階に分離し た架構重量と、各階の天井に設置したおもりの重量に相当するもの として、2 階梁に 1.713ton、1 階梁に 1.917ton、計 3.63ton をそれぞ れ 3 箇所に分けて配置した。1, 2 階の質量比は 0.894 となり、必要壁 量算定の際に仮定する単位面積あたりの重量によれば、重い屋根を 有する総 2 階の建物とほぼ同等である。減衰は文献 7 の 1 層モデル において初期剛性比例型で $0.5 \%$ となるように各部材に与えており、 2 層モデルでも同じ減衰係数を各部材に与えた。なお、 2 層モデルて も微小变位における 1 次の減衰定数がほぼ $0.5 \%$ となることを確認し ている。対象とする加振は JMA 神戸波 NS 方向を最大加速度 $0.6 \mathrm{~g}$ に基準化したもので、解析には振動台実験で計測された土台の加速 度を用いた。ただし、-VW- $/ \mathrm{VW}-\mathrm{VW}$ 架構と-FW-/FW-FW 架構は架構の耐 力が高いため、JMA 神戸波原波 $(0.83 \mathrm{~g})$ を入力した。解析時間は 10 秒、時間刻みは 0.001 秒である。

\section{2 全体応答およびダンパー挙動の比較}

振動台実験とフレームモデルによる地震応答解析の全体応答の比 較として、図 7 に層間変形の時刻歴、層せん断力 $Q$-層間変形 $\Delta u$ 関係およびダンパーの荷重一変形関係の比較を示す。

$-1.6 W-/ W-W$ 架構では最大変形は概放一致しているが、1 階の正側 で包絡線が一致していない部分がある。これは負側で生じた大きな 損傷が正側に及ぼす影響を解析で考慮していないためである。各階 に制振壁を配置した架構では解析と実験が良く一致している。合板 壁と制振壁を併設した架構ではダンパー変位が若干低いものの、そ の他については解析と実験が 1,2 階とも良く合っており、最大変形 の誤差は $15 \%$ 以下であった。

一方、 $-1.2 \mathrm{~W}-/ \mathrm{W}-\mathrm{W}$ 架構では 1 階の合板壁で、-1. 6W- $/ \mathrm{V}-\mathrm{V}$ 架構と $-1.6 \mathrm{~W}-/ \mathrm{F}-\mathrm{F}$ 架構では 2 階の合板壁で、剛性・耐力が解析と実験で若 干異なっていた。同じ仕様でそれらが一致する架構もあることから、 異なる原因は実験時の木材自身や施工によるばらつきの影響と考え、 図 7 では当該階の合板壁の釘量 (釷のせん断力ーすべり関係におけ る剛性・耐力) を試行錯誤的に最大で 2 割まで増減させた結果を示 している。釘量調整の結果、実験と解析は良く一致し、-1.6W-/F-F

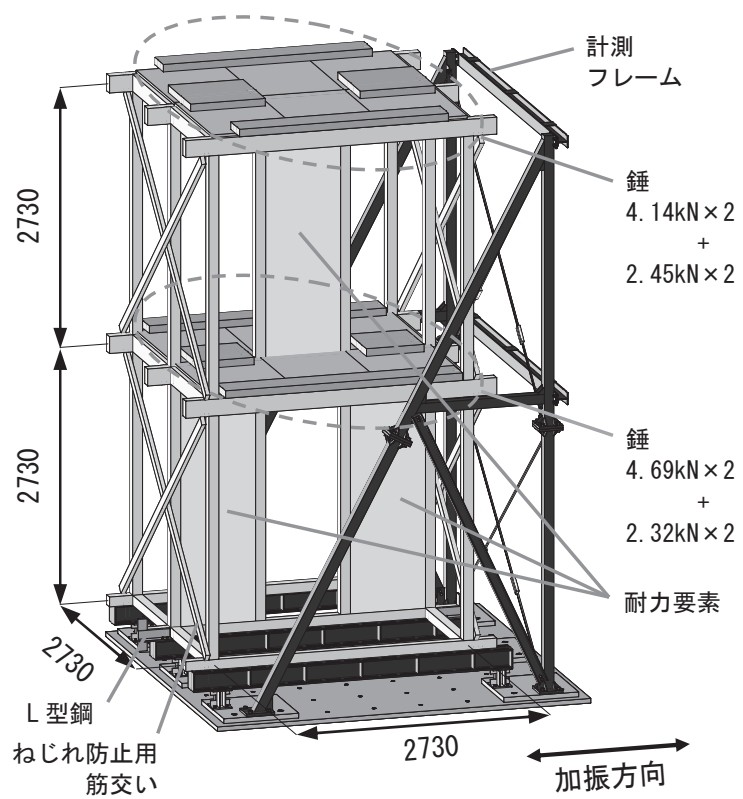

図 5 比較対象とする振動台実験 ${ }^{3)}$

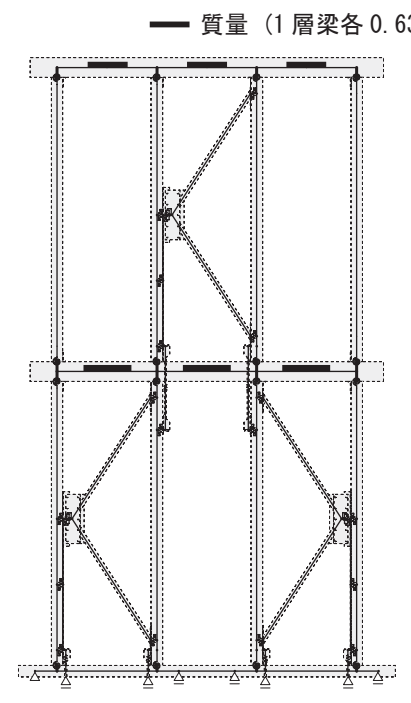

(a) $-\mathrm{V}-\mathrm{V}-\mathrm{V}$

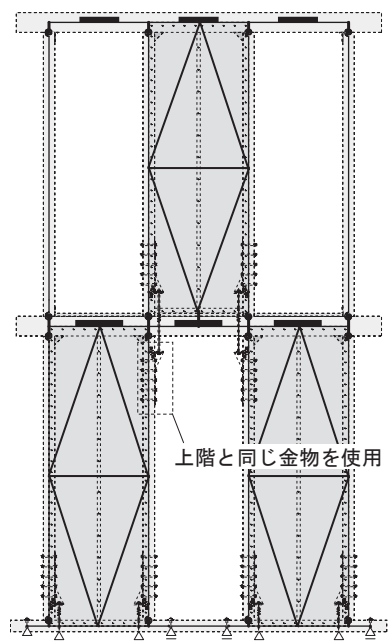

(b) $-1.6 \mathrm{~W}-/ \mathrm{W}-\mathrm{W}$
図 6 フレームモデルの例

架構では残留変位も再現できる結果となった。しかし、釘量の調整 前は解析と実験の結果に大きな差が見られ、これについては 4.1 節 で詳述する。

\section{3 局所応答の比較}

振動台実験では柱横架材接合部の回転角・引き抜け変形および引 き寄せ金物のボルト軸力を計測しているため、それらの実験結果と 解析結果の比較を行う。架構はほぼ左右対称の形状であるため、紙 面の都合上 $-\mathrm{V}-\mathrm{V}-\mathrm{V}$ 架構と-1. $6 \mathrm{~W}-/ \mathrm{W}-\mathrm{W}$ 架構の左半分についてのみの 比較を図 8 に示す。

柱頭柱脚接合部の回転角は層間変形角にある程度追従するため、 精度が高いことがわかる。-V-/V-V 架構の 1 階中柱の柱頭では 1 階 の壁用の金物が左側に、2 階引き寄せ金物の反力金物が右側に取り 付いており、両側に金物が付いているため、回転への抵抗が強く生 じる回転角も小さいが、そのような傾向も一致している。 


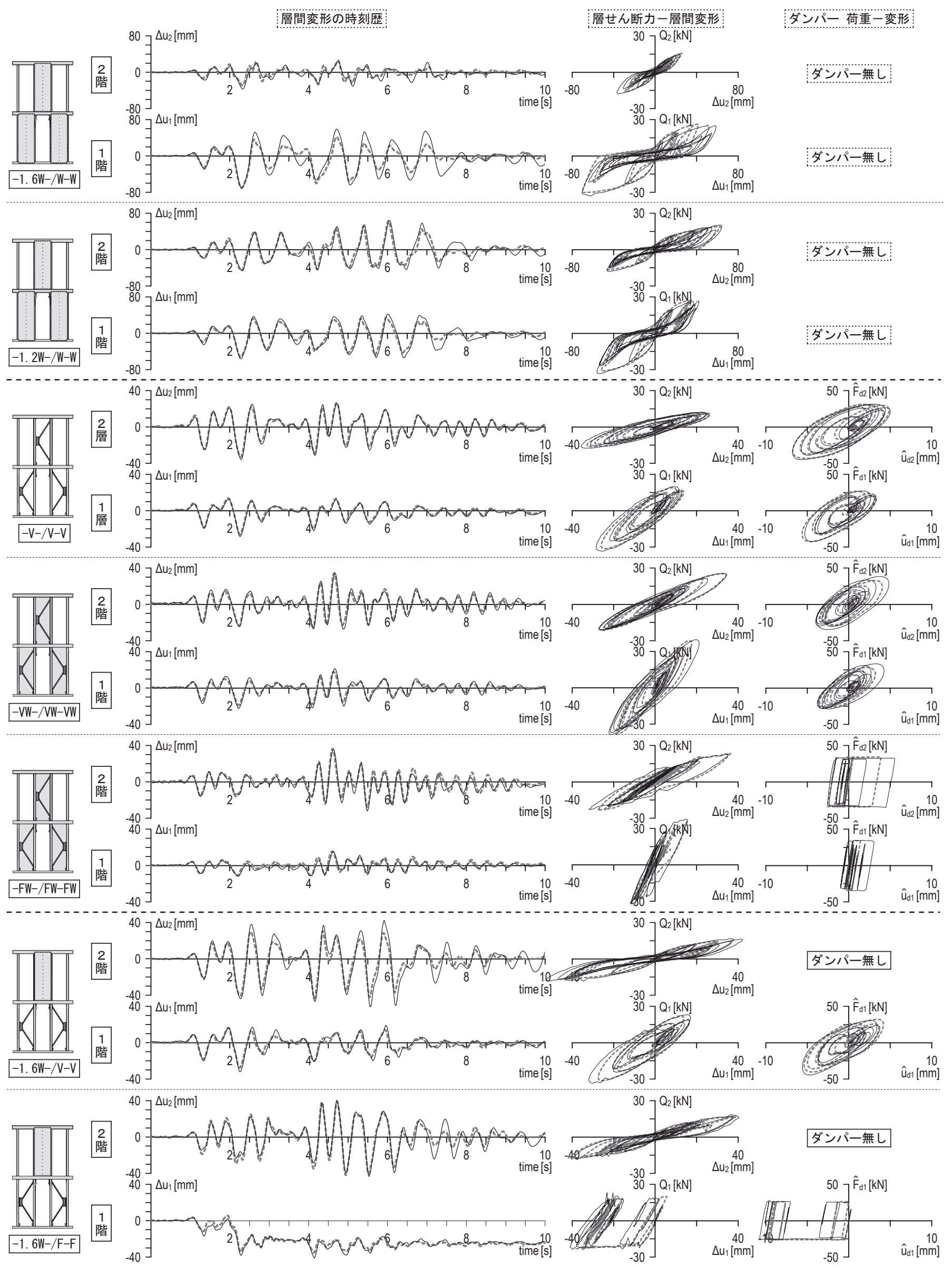

図 7 J MA 神戸 $0.6 \mathrm{~g}$ 入力時の 2 層木質架構の振動台実験 $\left.{ }^{3)}, 4\right)$ とフレーム解析の比較—— 実験 - - - 解析 $(-\mathrm{VW}-/ \mathrm{VW}-\mathrm{VW}$ と-VF-/VF-VF は JMA 神戸 $0.83 \mathrm{~g}$ 入力時 $)$ 

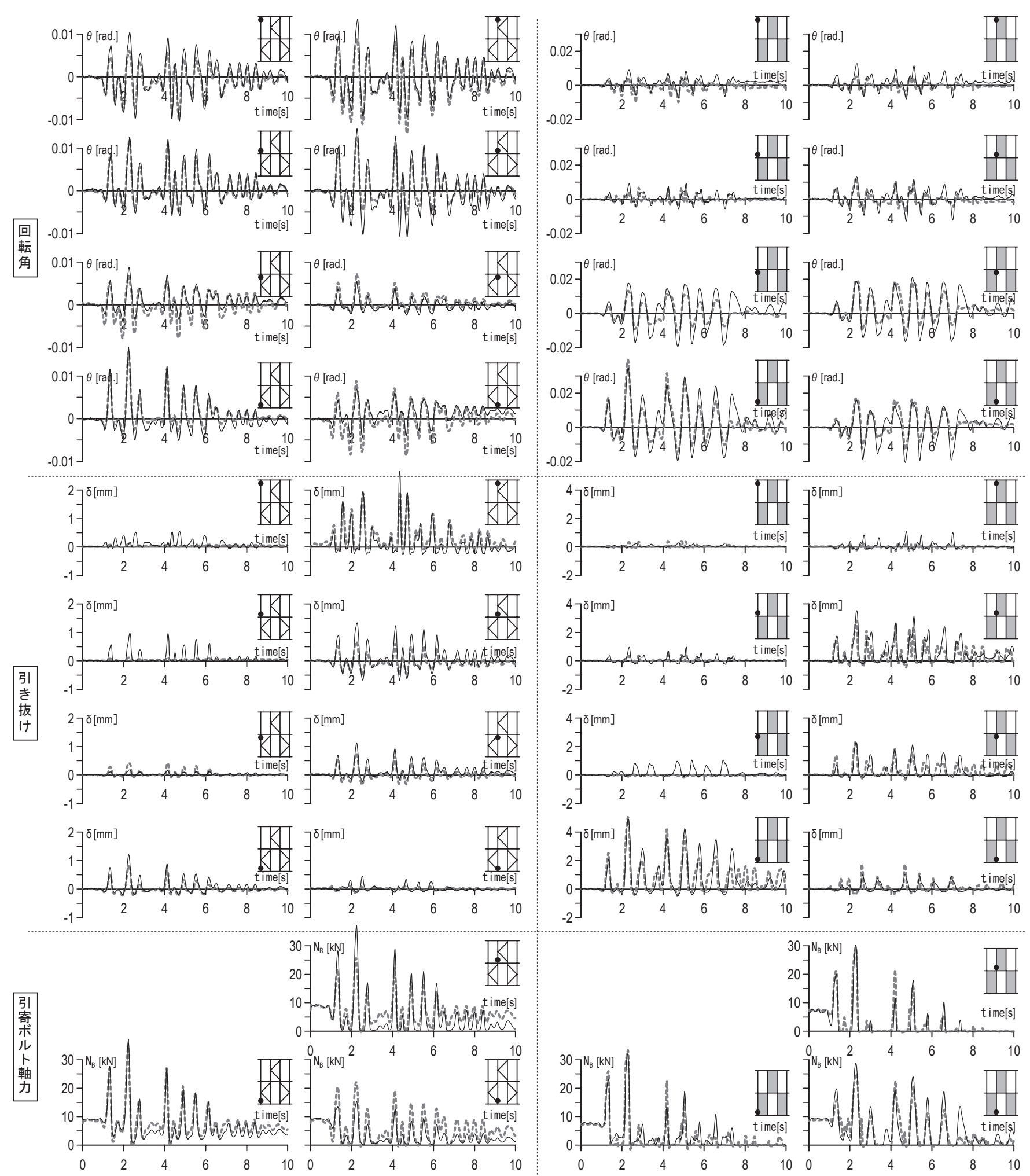

(a) $-\mathrm{V}-\mathrm{N}-\mathrm{V}$ 試験体

— 実験

- - - 解析

(b) $-1.6 \mathrm{~W}-/ \mathrm{W}-\mathrm{W}$ 試験体

図 8 JMA 神戸 $0.6 \mathrm{~g}$ 入力時の 2 層木質架構の振動台実験 ${ }^{3)}$, 4) とフレーム解析の局所応答の比較

柱頭柱脚接合部の引き抜けは文献 7 と同様、引張力がほとんど生 じない接合部において、回転により誘発される引き抜けを再現する ことができないため精度が良くない。ただし、それ以外は全体的に 概放良く合っているといえる。なお、 $-\mathrm{V}-\mathrm{V}-\mathrm{V}-\mathrm{f}$ 架構の 2 階中柱の柱 頭では、実験中の金物設置ミスのため引き抜けが大きくなっている が、それも良く再現できている。
引き寄せボルトの軸力は-V-/V-V 架構の 2 階で若干精度が劣るが、 それ以外は実験と解析が良く一致している。柱の引張力により生じ るボルト軸力だけでなく、接合部の回転により生じるボルト軸力も 概ね再現できている。このように、全体応答だけでなく局所応答も 含め、作成したフレームモデルは実験を精度良く再現できているこ とが確認できる。 
4.スリップ型復元カ特性が全体応答に及ぼす影響

\section{4. $1-1.2 W-/ W-W$ 架構の解析精度検証}

3.2 節で述べたように、 $-1.2 \mathrm{~W}-/ \mathrm{W}-\mathrm{W} 、-1.6 \mathrm{~W}-/ \mathrm{V}-\mathrm{V} 、-1.6 \mathrm{~W}-/ \mathrm{F}-\mathrm{F}$ 架 構で釘量の調整を行う前は、各階の $Q-\Delta u$ 関係における剛性・耐力 が実験と解析で概ね一致しているにもかかわらず、実験と解析の応 答変位が大幅に異なっていた。 $-1.2 \mathrm{~W}-/ \mathrm{W}-\mathrm{W}$ 架構を例にその挙動につ いて説明する。1 階のみ合板壁の釘量を元の 1.00 倍から 1.15 倍まで 0.05 倍ずつ変化させた場合の全体挙動の変化を図 9 に示す。釘量を 1.00 倍から 1.15 倍に変化させても 1 階の時刻歴挙動の変化は少ない が、2 階は大きく変化しており、特に加振後半の挙動が変化するこ とにより実験結果と解析結果がほぼ一致する結果となっていること がわかる。

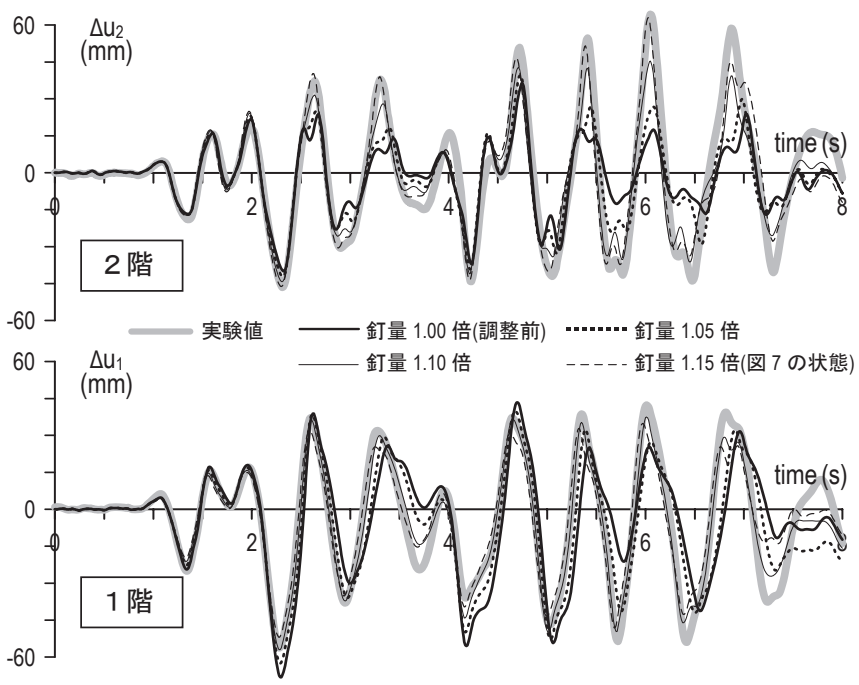

図 91 層合板壁の釘量調整による層間変形時刻歴の変化

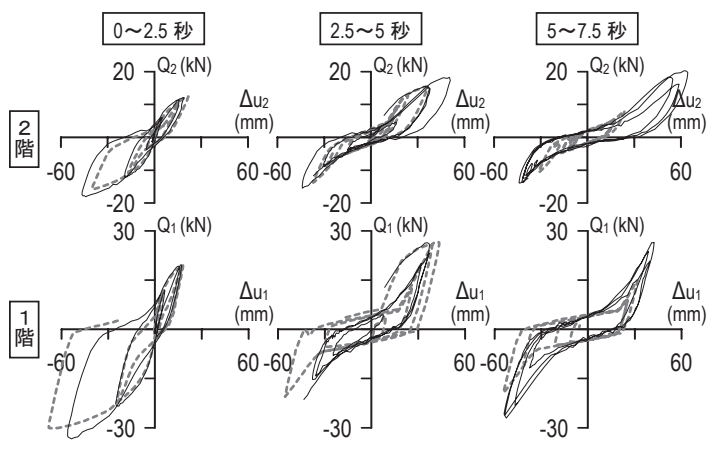

(a) 釘量 1.00 倍の場合
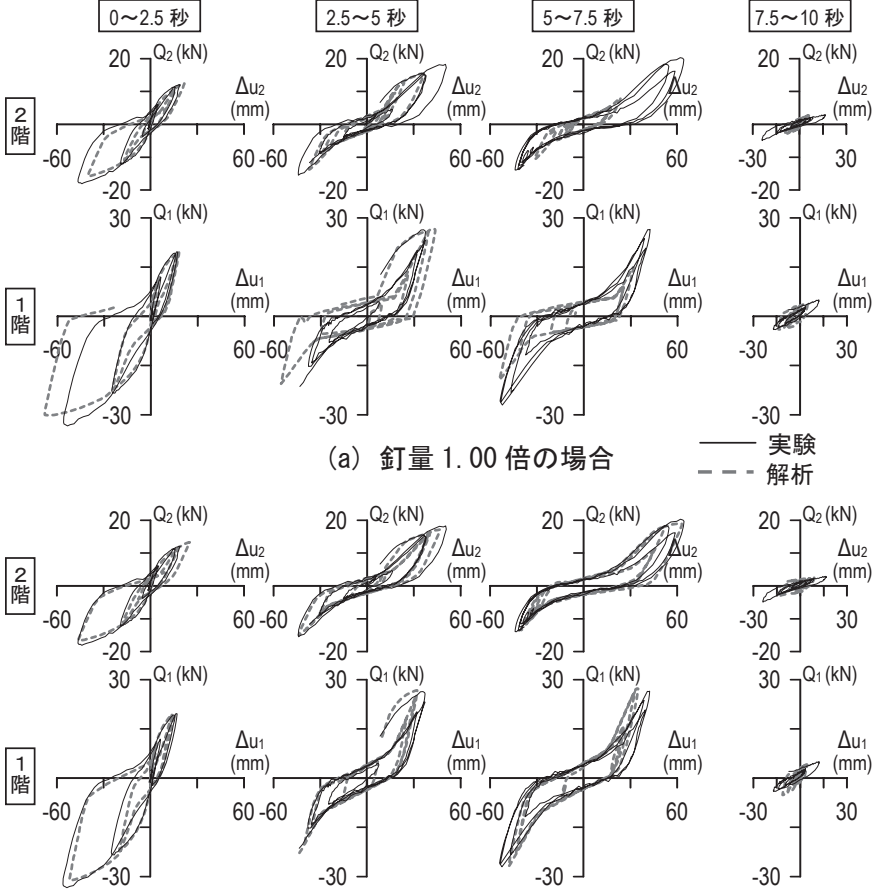

(b) 釘量 1.15 倍の場合
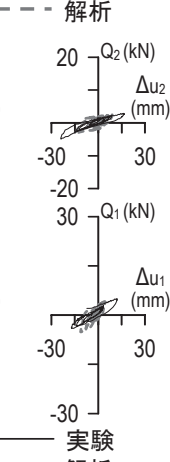

- - - 解析

図 101 層合板壁の釷量調整による $Q-\Delta u$ 関係の変化

図 10 で時間毎に $Q-\Delta u$ 関係を見ると、2.5 秒までに 1 階が最大変 形に到達している。1.00 倍のモデルでは実験よりも最大変形が大き く、その違いにより 2.5〜7.5 秒における 1 階のスリップ時の岡性が 実験と解析で異なっている。一方 1.15 倍のモデルでは、1 階の最大 変形が実験と一致し、その後の 1 階のスリップ時の剛性も一致する ことにより、2 階の挙動も実験と一致したことを確認できる。この ように、スリップ挙動が顕著となる架構では、最大変形が増大寸る につれてスリップ時の剛性が徐々に変化する ${ }^{7)}$ 。その微妙な違いで その後の挙動が著しく変化するため、スリップ後の挙動を予測する ことが困難になるとともに、実際の建物応答もばらつきが大きくな ることを示唆している。

\section{21 階と 2 階の質量・剛性バランス}

前節で示したように、スリップ挙動を持つ架構では 1,2 階の僅か な剛性バランスの変化により、変形モードが著しく変動することを 確認した。このような関係は 1,2 階の質量及び剛性バランスで変化 することが容易に想像できる。そこで、前節と同様に-1. 2W-/W-W 架 構において、 1 階の釘量を 0.5 倍から 1.5 倍まで 0.05 刻みで変化させ たパラメトリック解析を行った。パラメトリック解析ではレベル 2 入 力を想定した6つの地震動を入力した。それらはBCJ-L2 波、TaftN111E、 八戸 $\mathrm{EW}$ 、東北大学 NS、El Centro NS、JMA 神戸 NS の位相特性を持つ 模擬地震動 ${ }^{14)}$ で、減衰定数 $2 \%$ 時の短周期の加速度一定領域で $S_{p a}=$ $1375 \mathrm{~cm} / \mathrm{s}^{2} 、 5 \%$ 時で $S_{p a}=1000 \mathrm{~cm} / \mathrm{s}^{2}$ 程度となるように設定したものであ る。なお、解析では質量比 $\alpha=0.894$ である。

横軸を釘量比、縦軸を変形モード $\phi_{2} / \phi_{1}\left(\phi_{1}, \phi_{2}\right.$ は地面から 1,2 階の 相対変位) として解析結果を図 11 に示寸。ここで-1.2W-/W-W 架構の場合、 2 階の釷量 1.2 を 1 階の釷量 $1.0 \times 2$ で除寸ため 0.6 となる。また、参考 として 2 質点弾性系における 1,2 階の質量比 $\alpha\left(=m_{2} / m_{1}\right)$ および岡性比 $\beta\left(=k_{2} / k_{1}\right)$ から求まる変形モードの弾性理論曲線付録3) も示している。弾 性理論上は剛性比 $\beta$ がある程度高ければ、 $\beta$ の変化に伴い変形モー ド $\phi_{2} / \phi_{1}$ は比較的緩やかに変化することが見てとれる。一方、パラ メトリック解析の結果では、 $\beta$ の変化に伴い弾性理論值よりも急激 に変形モードが変化しており、損傷集中階の移り変わりは弾性理論 值よりも剛性比に敏感であることが確認できる。

壁量設計における必要壁量算定の際に仮定する単位面積あたりの 重量例えば 15) を考慮すると、必要壁量を最低限満たす場合、総 2 階の 重い屋根で質量比 $\alpha=0.86$ 、剛性比 $\beta=0.64$ であり、図 11 の損傷階 が変化する境界 $\left(\phi_{2} / \phi_{1}=2\right)$ に位置する。2 階の面積が 1 階より小さ

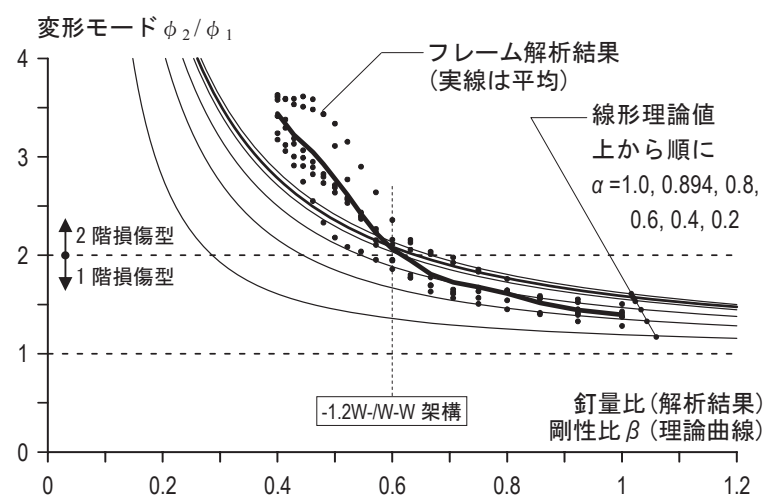

図 111,2 層の質量比 $\alpha \cdot$ 剛性比 $\beta$ の変化による変形モードの推移 
い場合、もしくは軽い屋根の場合は更に 2 階が損傷する方向に向か うことが確認できているが、一般に戸建住宅は 1 階損傷集中型のモ 一ドになることを考えると、非構造材の影響で岡性比 $\beta$ が変化して いるものと推測される。実務で構造解析をする場合、非構造材の影 響を無視することも多く、解析結果を議論する際はその点を把握し ておく必要があるといえる。

\section{5．壁の配置・設置方法の違いが及ぼす影響}

\section{1 検討内容およびモデルの作成方法}

実験では壁の配置を市松状配置としたが、実際の建物では連層と なることも多い。また、3 章の解析モデルでは 2 階引き寄せボルト の反力を直下の柱からとったが、耐震補強を行う際や上下階で柱が ずれる場合は 1 階の梁から反力をとるケースも考えられる。そこで、
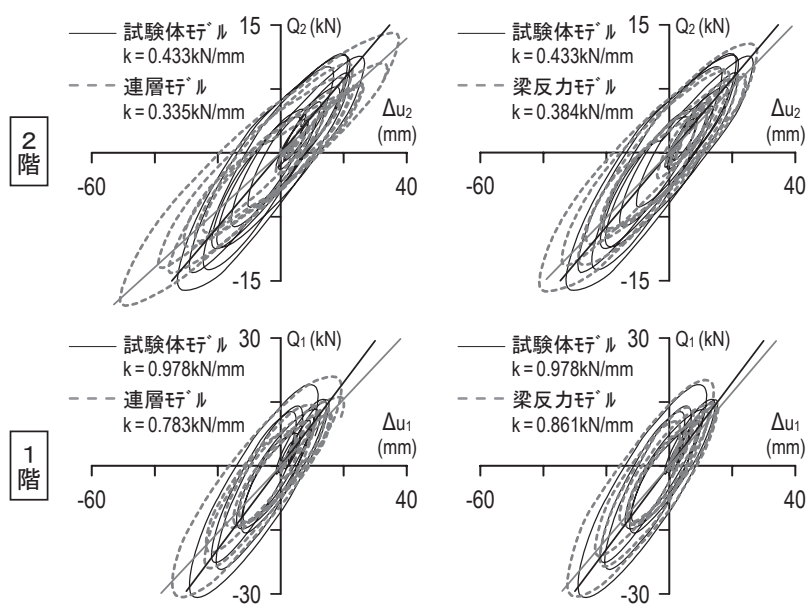

（a）試験体玩゙ルvs 連層玩゙ル

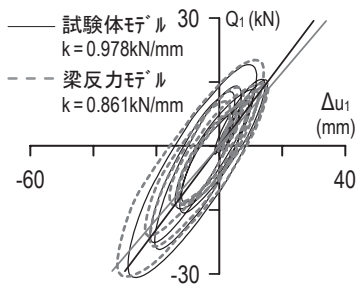

（b）試験体モデル vs 梁反力モデル
それらのケースにおける制振壁のエネルギー吸収性能について本フ レームモデルを用いて検討を行う。以後、3 章のモデルを試験体モ デル、壁配置を連層にしたものは連層モデル、2 階引き寄せボルト の反力を 1 階梁からとったものは梁反力モデルと称す。なお、梁反 力モデルでは、ボルトの軸バネを梁に対して直に接続した。入力は JMA 神戸 $0.6 \mathrm{~g}$ とした。

\section{2 全体応答·局所応答の比較}

粘弹性ダンパー系における各階の $Q-\Delta u$ 関係について、試験体モ デルとの比較を図 12 に示す。試験体モデルに対し、連層モデルでは 各階で剛性が $20 \%$ 程度低下し、最大応答変位は 2 階で約 $50 \%$ 増加 している。また、梁反力モデルでは各階で剛性が $8 \%$ 程度低下し、 最大応答変位は 2 層で約 $25 \%$ の増加となり、両モデルとも試験体モ デルより剛性が低下した。ここで、1 階が最大層せん断力に達した ときの柱の軸力分布および柱頭柱脚の柱・横架材間の相対変位を図 13 に示す。図 13 では引張力および引き抜け変位を正の值で示し、 $N$ 図では柱の右側を正とする。なお、変形は 1 次モードが卓越してお り、このとき 2 階でもほぼ最大層せん断力に達していた。

(b)連層モデルの場合、2 階の壁の柱脚に生じる柱軸力が、ほぼ 1 階柱に引き継がれるため、直下の壁には軸力が集中する。このよう なケースの対応として、壁倍率を用いた設計では $\mathrm{N}$ 值計算等により 壁の配置を考慮して使用する金物を決定する。一方、制振壁では壁 の仕様として金物の種類を決めているケースも多く、壁配置による 接合部の設計法については検討の必要があるといえる。

一方、(c)梁反力モデルの場合、1 階の左側中柱の柱頭で引張力が 大きくなり、それに伴って引き抜け変位が増大していることがわか る。これは直上の柱に大きな引張力が生じるのに対し、柱とその直 下の梁が引き寄せボルトおよび柱脚金物で強くとめつけられている ため、梁が曲がり、相対的に弱い直下の柱頭部に変形が集中したた めである。梁の曲げ剛性を強化する、もしくはより剛強の金物を直 下の柱頭に配置することで上記問題は減少するが、基本的には直下 の柱から反力をとる方が効率的である。
図 12 粘弾性ダンパー系の各モデルの荷重一変形関係 (図中の $\mathrm{k}$ および直線は最小二乗法で求めた剛性)

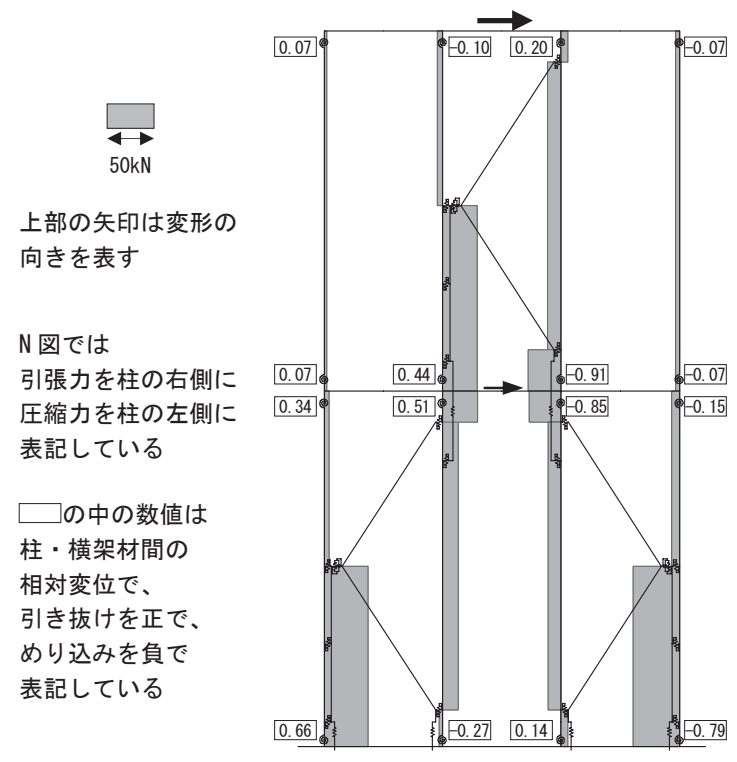

（a）試験体モデル

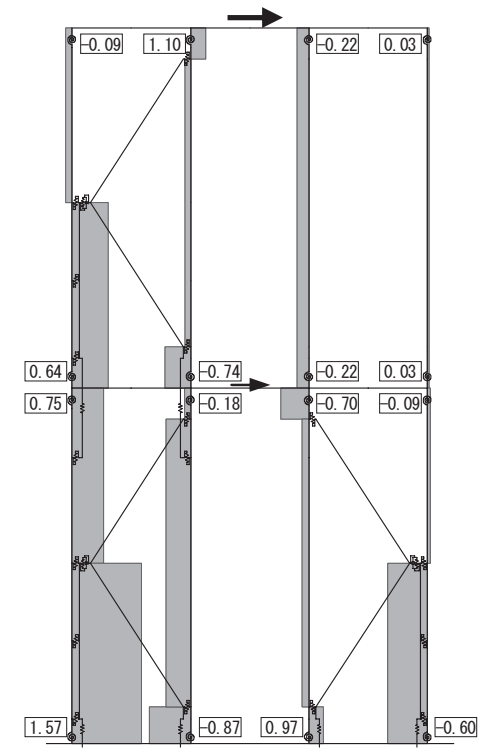

(b) 連層モデル

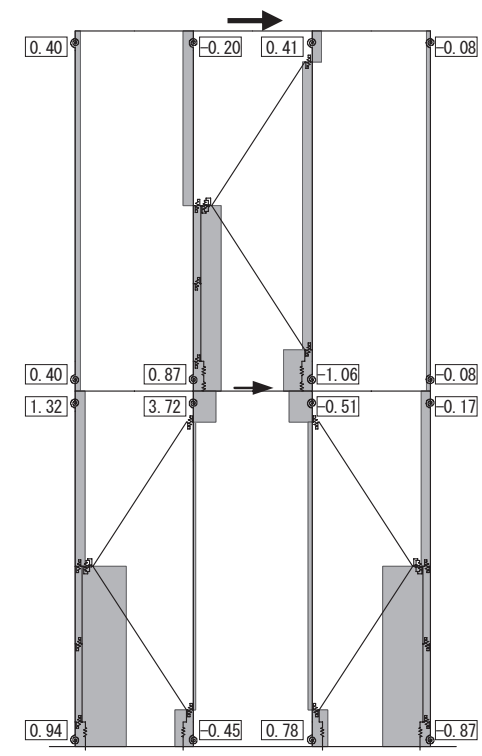

（c）梁反カモデル

図 13 粘弾性ダンパー系の 1 階最大耐力時における柱軸力分布 $(\mathrm{N}$ 図) と柱頭柱脚の柱・横架材間の相対変位 


\section{3 局所変形の寄与割合}

2 層架構における变形状態および記号の定義を図 14 に示寸。一般 に壁試験で真のせん断変形角を求める際、柱脚部の柱引き抜けによ るロッキング変形の寄与分を層間変形角 $\theta$ から引くことにより求め る。ただし、基礎から反力をとる引き寄せ金物以外に、土台と柱を 金物で固定する場合、土台の曲げによる浮き上がりも同様にロッキ ング変形を引き起こす要因となる。そこで、 1 階のロッキング変形 $\theta_{R 1}$ の算定には式(1)を用いる。また、図 14 に示すように 2 階に配置した 制振壁では 1 階のロッキング変形に加え、1 階柱の軸変形、1 階柱頭接 合部の柱引き抜け、2 階柱脚接合部の柱引き抜けが影響すると考えられ る。すなわち、2 階のロッキングによる変形角 $\theta_{R 2}$ の算定には式(2) を用いることとした。

$\theta_{R 1}=\frac{\left(\delta_{S-L}-\delta_{S-R}\right)+\left(\delta_{B a 1-L}-\delta_{B a 1-R}\right)}{L}$

$\theta_{R 2}=\theta_{R 1}+\frac{\left(\delta_{C o 1-L}-\delta_{C o 1-R}\right)+\left(\delta_{C a 1-L}-\delta_{C a 1-R}\right)+\left(\delta_{B a 2-L}-\delta_{B a 2-R}\right)}{L}$

ここに、式(1)右辺分子の 1 番目の括弧が土台曲げの寄与、 2 番目が 1 階 柱脚接合部の軸変形の寄与であり、式(2)右辺分子の 1 番目の括弧が 1 階柱軸変形の寄与、 2 番目が 1 階柱頭接合部の軸変形の寄与、 3 番目が 2 階柱脚接合部の軸変形の寄与である。

本制振壁では、(1)ロッキング変形を表すバネ、(2)ダンパー変形を 表すバネ、(3)その他局所変形を表すバネ、以上 3 つのバネの直列系 でダンパー変位が決定すると考え、各バネの寄与の割合を求めた結 果を表 2 に示す。(1)ロッキング変形の寄与は式(1), (2)から、(2)ダン パー変形の寄与は幾何学的関係からダンパー変位を 3 倍した值の層 間変形に対する割合とし、その他の寄与は(1)、(2)を 1 から引くこと で求めた。

摩擦ダンパー系の場合、粘弾性ダンパー系の同じモデルと比べて 全てのモデルでダンパー変位の割合が上昇している。これは摩擦ダ ンパーの場合、滑ることによりダンパー荷重が頭打ちとなり、粘弾 性ダンパーよりも荷重が小さくなることで周辺部材の変形が抑えら れたためである。

粘弾性ダンパー系の場合、1 階は試験体モデルのダンパー変形の 寄与が最も高い。試験体モデルの 2 階はダンパー変位の寄与が 1 階 より低いものの、土台の曲げや 1 階柱脚の軸変形が 2 階のダンパー 変形を増幅させる方向に寄与しているため、他のモデルの 2 階より ダンパー変形の寄与が大きい。このように、壁の市松状配置の有効

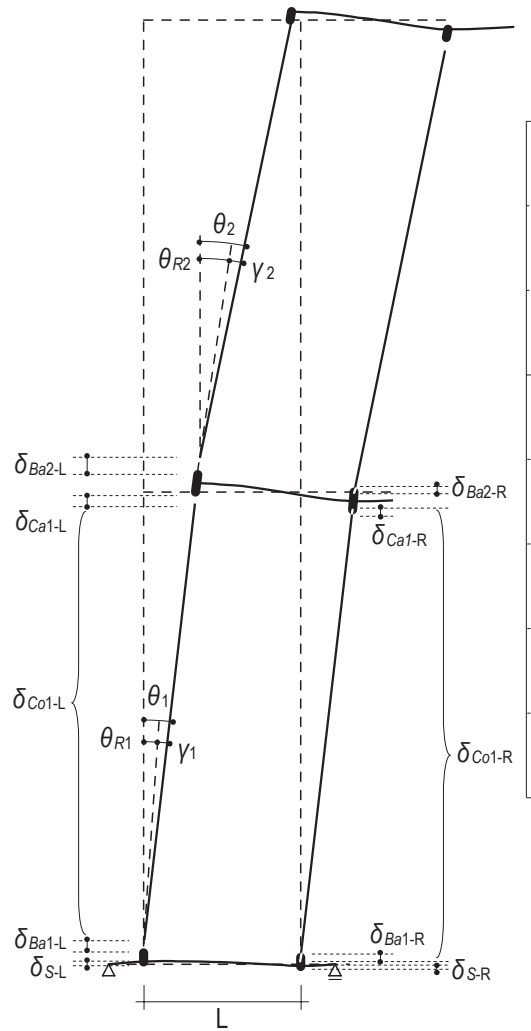

\begin{tabular}{l}
$\theta_{i}:$ \\
$i$ 階の層間変形角 \\
$\theta_{R i}:$ \\
i 階のロッキング変形角 \\
\hline
\end{tabular}

i 階の真のせん断変形角

$\delta_{\mathrm{Ba} 2}:$

2 階柱脚の軸変形

$\delta_{c a 1}$ :

1 階柱頭の軸変形

$\delta_{c 01}$ :

1 階柱の軸変形

$\delta_{B a 1}:$

1 階柱脚の軸変形

$\delta_{S}$ :

土台の柱軸方向変形

注)

末尾の L, R は左図の

左・右柱を意味する

図 $14 \quad 2$ 層架構の変形状態および記号の定義

性を確認できる。

連層モデルの 1 階左では、図 13 で示したように柱軸力が大きくな ったことにより柱の引き抜けの割合が高く、ダンパー変形の寄与は 全モデルで最も低い。2 階ではロッキング変形の要因となる各寄与 が全体的に大きく、それによりダンパー変形の寄与が著しく低下し ていることがわかる。

梁反力モデルでは壁配置を市松状としているため、2 階は試験体 モデルの 2 階と同様に、土台の曲げおよび 1 階柱脚軸変形の寄与が 小さい。しかし、図 13 で示したように 1 階柱頭の軸変形による寄与 が増大し、ダンパー変位が減少している。

その他の寄与としては、柱・横架材接合部のせん断変形、ブレー スの軸変形、 $\mathrm{K}$ 型架構と軸組間を留めるビスのせん断変形などが影 響するが、それらの和は全モデルで概ね等しく、かつ比較的小さい

表 2 層間変形に対する各局所変形寄与の割合

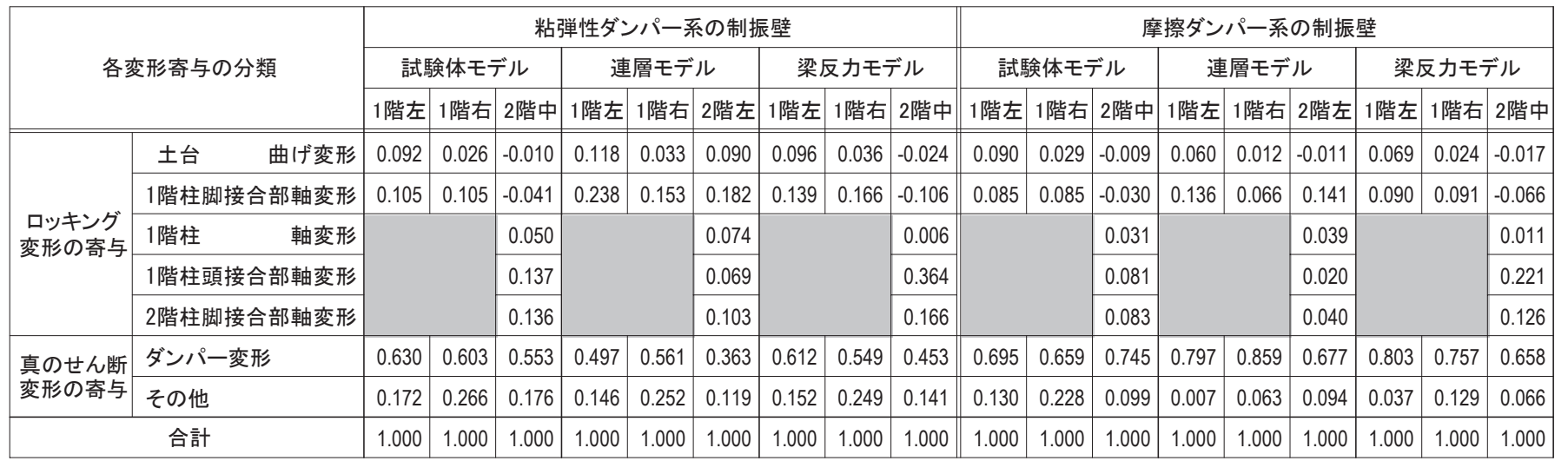


ことから、本制振壁ではロッキング変形の制御が重要であることを 確認できる。一般に木質架構の実験では柱脚接合部の柱軸変形を計 測することが多いが、2 階の壁では 2 階柱脚接合部の軸変形以外に、 上述した直下階の 4 つの変形寄与が複合的に影響することを確認で きる。2 階の壁のロッキング変形を検討する場合には、それらの影 響も考慮に入れる必要があるといえる。

\section{4 各モデルのエネルギ一吸収性能}

上記 3 モデルにおける各制振壁のエネルギー吸収性能を、制振壁 単体(1P)におけるエネルギー吸収性能と比較するために以下の検討 を行った。5.2 節の地震応答解析から得られた層間変形の時刻歴波形 を、1Pの壁モデルの梁に強制変形で与えた。その時のダンパーのエ ネルギー吸収量を基準と考え、上記 3 モデル内に配置されたダンパ 一のエネルギー吸収量と比較した。検討の結果を表 3 に示す。

粘弾性ダンパー系の試験体モデルでは 1 階のダンパーが制振壁単 体の場合に対して 1.3 倍ものエネルギーを吸収しているが、 2 階のダ ンパーはそれよりも性能が低い。しかし、それでも1P の制振壁と ほぼ同等の性能を発揮したことがわかる。連層モデルでは 2 階の制 振壁の性能が一番低いだけでなく、2 階の影響を受けて直下の 1 階 左もエネルギー吸収性能が大幅に低下している。梁反力モデルでは 2 階のエネルギー吸収性能が低く、1 階制振壁は制振壁単体より性能 が高いものの、試験体モデルと比べると低い

摩擦ダンパー系の場合、ダンパーの滑り荷重は変化しないため架 構の降伏荷重も変化せず、エネルギー吸収効率の違いは架構の弾性 剛性に現れる。各モデル間のエネルギー吸収効率の大小関係は粘弾 性ダンパー系とほぼ同じで、試験体モデルの 1 階が最も高く、連層 モデルの 2 階が最も低い。図 15 からわかるように、エネルギー吸収 効率の大小関係に応じて、基準となる $1 \mathrm{P}$ モデルから弾性剛性が変 化している。

2 階に $\mathrm{K}$ 型ブレース制振壁を配置する場合、最も効率的な配置を した試験体モデルでも制振壁単体の場合と同程度の性能であったこ とから、ロッキング変形の増加に伴うエネルギー吸収効率の低下を 考慮する必要があると考えられる。また、1 階の制振壁においても 上階の壁配置が影響することから、それを踏まえた接合部の設計、 制振壁の設計手法が必要といえる。1P モデルの性能は設計時に想定 する性能と考えることもできるが、架構内に配置された場合、それ とは明らかに挙動が変化するケースも確認できた。このような挙動 の違いを一般的なせん断棒モデルでは再現することができないため、 解析モデルを作成する際には注意を要するといえる。

\section{6.おわりに}

文献 7 で作成した制振壁・合板壁による精密な 1 層木質制振架構 のフレームモデルを 2 層木質制振架構にも適用できるよう拡張した。 フレームモデルの地震応答解析と 2 層木質制振架構の振動台実験と の比較を行うとともに、 1,2 階の質量比・剛性比との関係や、 2 階に 配置した制振壁の挙動、およびそれが 1 階に及ぼす影響についても 言及した。以下に要約する。

・文献 7 では 1 層木質制振架構の部材を個々にモデル化しており、 柱脚部では接合部と引き寄せボルトを分けてモデル化している。 そのため、2 階の引き寄せボルトのバネを変更するのみで、 2 層の フレームモデルを作成した。そのモデルは架構の荷重一変形関係
表 32 層架構におけるダンパーのエネルギー吸収量と 制振壁単体(1P)のダンパーのエネルギー吸収量の比較

\begin{tabular}{|c|c|c|c|c|c|c|c|}
\hline & \multicolumn{3}{|c|}{ 粘弾性ダンパー系の制振壁 } & \multicolumn{3}{|c|}{ 摩擦ダンパー系の制振壁 } \\
\hline & & $\begin{array}{c}\text { 試験体 } \\
\text { モデルル }\end{array}$ & $\begin{array}{l}\text { 連層 } \\
\text { モデルル }\end{array}$ & $\begin{array}{c}\text { 梁反力 } \\
\text { モデル }\end{array}$ & $\begin{array}{c}\text { 試験体 } \\
\text { モデル }\end{array}$ & $\begin{array}{l}\text { 連層 } \\
\text { モ寺ル }\end{array}$ & $\begin{array}{c}\text { 梁反力 } \\
\text { モデルル }\end{array}$ \\
\hline \multirow{3}{*}{$\begin{array}{l}\text { 2層 } \\
\text { モデル } \\
\text { (エネル } \\
\text { ギー) }\end{array}$} & 1階左 & 1349 & 1112 & 1433 & 203 & 549 & 372 \\
\hline & 1階右 & 1318 & 1836 & 1356 & 194 & 1480 & 346 \\
\hline & 2階 & 2247 & 2325 & 2002 & 1744 & 1559 & 1594 \\
\hline \multirow{3}{*}{$\begin{array}{l}1 P \\
\text { 王デル } \\
\text { (エネル } \\
\text { ギー) }\end{array}$} & 1階左 & 1030 & 1461 & 1181 & 137 & 980 & 380 \\
\hline & 1階右 & 982 & 1430 & 1134 & 88 & 769 & 306 \\
\hline & 2階 & 2195 & 3335 & 2541 & 1895 & 4188 & 2875 \\
\hline \multirow{3}{*}{$\begin{array}{l}\frac{2 \text { 層 }}{1 P} \\
\text { (比) }\end{array}$} & 1階左 & 1.309 & 0.761 & 1.214 & 1.482 & 0.561 & 0.980 \\
\hline & 1階右 & 1.342 & 1.284 & 1.195 & 2.220 & 1.925 & 1.130 \\
\hline & 2階 & 1.024 & 0.697 & 0.788 & 0.920 & 0.372 & 0.555 \\
\hline
\end{tabular}

(エネルギーの単位は $\mathrm{kN} \cdot \mathrm{mm}$ )

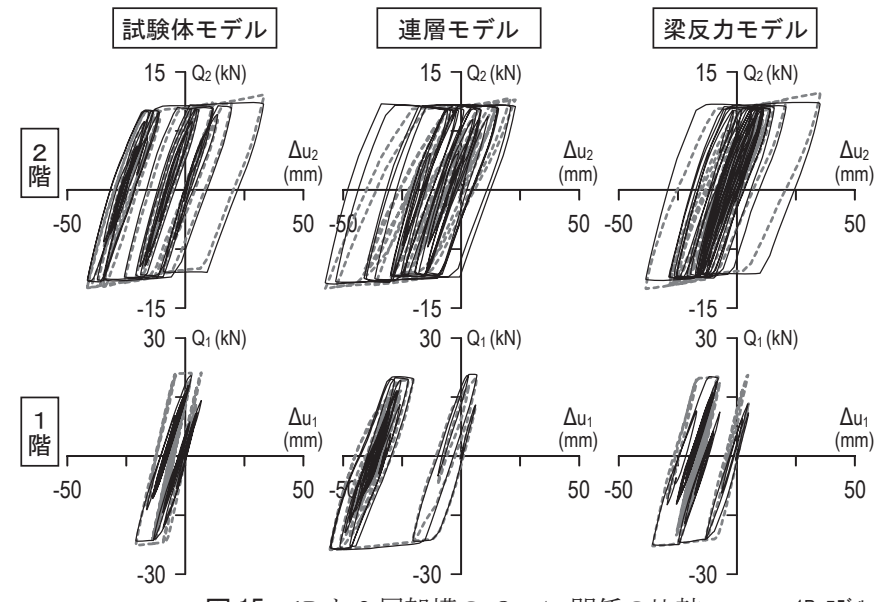

図 15 1P と 2 層架構の $Q-\Delta u$ 関係の比較—1P $\mathrm{t}^{\circ}$ (1 階では 1Pモデル2 個分の荷重を示している) - - 架構玨゙ル

といった全体応答だけでなく、ダンパーの荷重一変形関係や接合 部挙動といった局所応答でも、2 層木質制振架構の振動台実験 ${ }^{3), 4)}$ を精度良く再現できることを確認した。

・架構の荷重一変形関係でスリップ型の復元力特性が顕著に現れる 場合、最大変形が増大寸るにつれてスリップ時の剛性が徐々に変 化するため、スリップ後の挙動を予測することが困難になるとと もに、実際の建物応答もばらつきが大きくなると考えられる。

・1, 2 階の制振壁配置を市松状にした振動台実験の試験体モデルで は、2 階の制振壁のエネルギー吸収効率は 1 階の制振壁より低い ものの、1P の制振壁と同程度のエネルギー吸収性能を有していた。 1,2 階の制振壁配置を連層にしたモデルでは、2 階柱脚の軸力変動 が直下の柱に伝わることで、1 階壁の真のせん断変形角が小さく なり、2 階の壁では更に低下した。2 階の引き寄せ金物のボルト反 力を 1 階の梁から取ったモデルでは、 1 階の梁が曲がることによ り 2 階制振壁のエネルギー吸収効率が低下した。

・2 階壁の真のせん断変形を考える場合、2 階柱脚の軸変形だけでな く、土台の曲げ、 1 階柱頭・柱脚の軸変形、1 階柱の軸変形が複合 的に影響する。

・2 階に本制振壁を配置する場合、ロッキング変形の増加に伴うエ ネルギー吸収効率の低下を考慮する必要があると考えられる。ま 
た、1 階の制振壁においても上階の壁配置が影響することから、 それを踏まえた接合部の設計、制振壁の設計手法が必要になる。

\section{参考文献}

1) 笠井和彦, 坂田弘安, 和田章, 宮下健: K 型ブレースによるシアリンク制振 機構を用いた木質架構の動的挙動, 日本建築学会構造系論文集, 第 598 号, pp. 51-60, 2005.12

2) 坂田弘安, 笠井和彦, 和田章, 緑川光正, 大木洋司, 中川徹, 松田和浩: 速 度依存ダンパーをもつ木質架構の振動台実験，日本建築学会構造系論文集， 第 615 号, pp.161-168, 2007.5

3) 坂田弘安, 笠井和彦, 大小洋司, 松田和浩: 在来軸組戸建木造住宅を対象と した 2 層木質制振架構の振動台実験, 日本建築学会構造系論文集, 第 631 号, pp. 1607-1615, 2008.9

4) 松田和浩, 笠井和彦, 坂田弘安, 大木洋司: 財産保持に優れた制振住宅に関 する開発の経過報告 (その 21) 内外装材に着目した 2 層木質制振架構の振 動台実駼結果, 日本建築学会大会学術講演梗概集, B-2, pp.799-800, 2007.9

5) 笠井和彦, 蒲武川: 多層スリップ型架構に粘弾性ダンパーを用いた制振構造 の応答制御設計法, 日本建築学会構造系論文集, 第 650 号, pp. 781-790, 2010.4

6) 山崎義弘, 笠井和彦, 坂田弘安, 大木洋司: 剛性偏心した木質立体架構の粘 弹性ダンパーによる捩れ応答制御, 日本建築学会構造系論文集, 第 655 号, pp. 1691-1700, 2010.9

7) 松田和浩, 笠井和彦, 坂田弘安: フレームモデルによる木質制振架構の地 震応答解析, 日本建築学会構造系論文集, 第 661 号, pp. 609-618, 2011.3

8) (社)日本免震構造協会(JSSI)：パッシブ制振構造設計・施工マニュアル(第 2 版), 2005.9

9) 笠井和彦, 寺本道彦, 大熊潔, 所健 : 粘弾性体の温度 - 振動数 - 振幅依存 を考慮した構成則, その 1 線形領域における温度・振動数依存のモデル化, 日本建築学会構造系論文集, 第 543 号, pp.77-86, 2001.5

10) 笠井和彦, 所健: 粘弾性体の温度・振動数・振幅依存を考慮した構成則, そ の 2 温度上昇抢よび歪・歪速度がもたらす非線形性のモデル化, 日本建築 学会構造系論文集, 第 561 号, pp.55-63, 2002.11

11) 坂田弘安, 陶山高資, 松田和浩: 在来軸組住宅におけるビス・引寄せボル 卜を用いた接合部の履歴モデルに関する研究，日本建築学会構造系論文集， 第 645 号, pp. 2061-2067, 2009.11

12) 村上雅英, 稲山正弘: 任意の釷配列で打たれた面材壁の弾塑性挙動の予測 式, 日本建築学会構造系論文集, 第 519 号, pp. 87-93, 1999.5

13) (財) 日本住宅・木材技術センター: 木造軸組工法住宅の許容応力度設計 (2008 年版), 2009.6

14) 笠井和彦, 伊藤浩資 : 弾塑性ダンパーの剛性・降伏力・塑性率の調節によ る制振構造の応答制御手法, 日本建築学会構造系論文集, 第 595 号, pp. $45-55,2005.9$

15) 日本建築学会 : 木質構造基礎理論, 2010.12

\section{付録 1 : 分数微分を用いた粘弾性構成則}

粘弾性制振壁では式(A1)〜(A3)による粘弾性構成則のモデル9, 10)を用いた。

$$
\begin{aligned}
& \tau(t)+a D^{\alpha} \tau(t)=G\left[\gamma(t)+b D^{\alpha} \gamma(t)\right] \\
& a=a_{r e f} \lambda^{\alpha} \quad, \quad b=b_{r e f} \lambda^{\alpha} \\
& \lambda=\exp \left[-p_{1}\left(\theta-\theta_{r e f}\right) /\left(p_{2}+\theta-\theta_{r e f}\right)\right]
\end{aligned}
$$

ここで、式(A1)の $D^{\alpha}$ は分数微分演算子、 $\alpha$ は分数微分の次数であり、これ と $a, b, G$ が振動数依存のパラメータとなる。また、式(A2)の $a_{r e f}, b_{r e f}$ は基準温 度 $\theta_{r e f}\left(=20^{\circ} \mathrm{C}\right)$ でのパラメータ $a, b$ の值であり、式(A3)のパラメータ $p_{1}, p_{2}$ に より温度依存やエネルギー吸収による温度上昇と、それによる貯蔵剛性・損 失剛性の低下を考慮することができる。詳細は文献 9,10 )を参照されたい。

\section{付録 2：対象とした制振壁の詳細}

本論文では制振壁として文献 1)で提案した $\mathrm{K}$ 型ブレースによる制振壁を用 いた。本制振壁の形状および特徴は以下の通りである。図 A-1(a)のように K 型ブレースと柱側面の鋼板を鉛直方向に切り離し、地震時にその間に鉛直方
向の相効変位が生じることを利用してダンパーを変形させる、いわゆるシア リンク機構である。図 A-1(b), (c) に示寸鋼板 A および鋼板 B と鋼管はすみ肉 溶接で接合している。本架構に使用する引き寄せ金物は、鋼板 B に角鋼管を すみ肉溶接した独自のものになっている。鋼板 C と引き寄せ金物を一体にす ることにより、ダンパーに作用する力が引き寄せボルトおよび基礎に直接伝 わり、一体化しない場合に生じる部材・木材間のすべりを除去している。本 制振壁のディティールは、接合部の曲げ抵抗を抑え、ダンパーのエネルギー 吸収能力をできるだけ発揮させることを考えている。各部材やビス本数は高 めの安全率を設定しており、実用化の際には更なる軽量化が可能である。

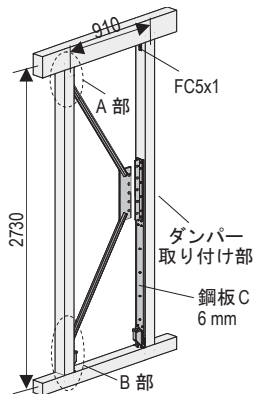

(a) 制振壁概観

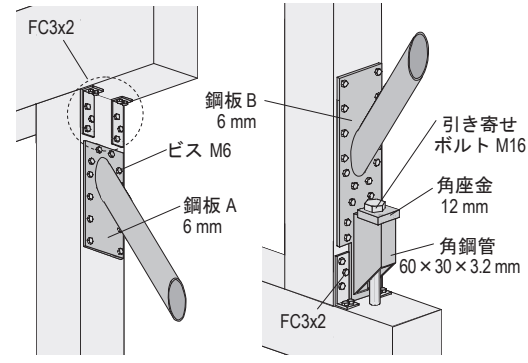

(b) $A$ 部詳細

图 $\mathrm{A}-1$ 制振架構試験体 (c) B 部詳細

\section{付録 3:2 質点弾性系の変形モードの理論解}

1,2 階の質量・剛性をそれぞれ $m_{1}, m_{2}$ および $k_{1}, k_{2}$ とし、1, 2 階の質量比を $\alpha\left(=m_{2} / m_{1}\right)$ 、剛性比を $\beta\left(=k_{2} / k_{1}\right)$ とする。弾性系のモード解析から、1 次の 変形モード $\phi_{2} / \phi_{1}\left(\phi_{1}, \phi_{2}\right.$ は 1,2 階の地面からの相対変位 $)$ は次式のように表 すことができる。

$$
\phi_{2} / \phi_{1}=1+\frac{1}{\beta}\left(1-\omega_{1}^{2} \frac{m_{1}}{k_{1}}\right)
$$

$\frac{\omega_{1}^{2}}{k_{1} / m_{1}}=\frac{\alpha \beta+\alpha+\beta-\sqrt{(\alpha \beta+\alpha+\beta)^{2}-4 \alpha \beta}}{2 \alpha}$

ここに、 $\omega_{1}$ は 1 次固有円振動数である。 